\title{
Differentiation of Neisseria gonorrhoeae strains by polymerase chain reaction and restriction fragment length polymorphism of outer membrane protein IB genes
}

\author{
Q C Lau, V T K Chow, C L Poh
}

\begin{abstract}
Objectives-To employ polymerase chain reaction (PCR) and restriction fragment length polymorphism (RFLP) analysis for the rapid differentiation of Neisseria gonorrhoeae protein IB (PIB) isolates and to compare its usefulness with the widely accepted auxotype/serovar classification scheme.

Methods-The outer membrane protein IB genes of 47 gonococcal isolates belonging to 10 different serovars were amplified by PCR. The $\sim 1 \mathrm{~kb}$ DNA products were then digested separately with restriction enzymes $C f o I$ and MspA1I, and electrophoresed on agarose gels.

Results-Cleavage of PIB genes by $M s p A 1 I$ and $C f o I$ differentiated all the $N$ gonorrhoeae strains into five and six PCR-RFLP profiles, respectively. PCRRFLP was more discriminatory than auxotyping, which classifies the strains into only two auxotypes. Some strains belonging to common serovars could be further differentiated. A combination of PCR-RFLP analysis, auxotyping and serotyping further increased the discrimination of the strains into 34 subtypes. The PCR-RFLP method was easy to perform, reliable, reproducible, and consistent with published nucleotide sequence data.

Conclusion-The PCR-RFLP method can augment auxotyping and serotyping or be used as a preliminary screening tool to differentiate $\boldsymbol{N}$ gonorrhoeae strains in areas where serotyping reagents are not easily available.
\end{abstract}

(Genitourin Med 1995;71:363-366)

Microbiology, Faculty of Medicine, National University of

Singapore, Lower

Kent Ridge Road,

Singapore 0511,

Republic of Singapore

Q C Lau

V T K Chow

C L Poh

Address correspondence to: DrVT K Chow, Department of

Microbiology, Faculty of Medicine, National

University of Singapore

Lower Kent Ridge Road

Singapore 0511 ,

Republic of Singapore

Accepted for publication

31 May 1995 this infectious disease is dependent upon antimicrobial treatment of infected persons, better education of the general public and effective epidemiological tools for monitoring gonococcal strains. Various typing schemes have been developed for the characterisation of $N$ gonorrhoeae isolates. Currently, the most widely accepted classification scheme is based on the dual combination of auxotyping and serotyping. ${ }^{1}$ Auxotyping has its limitations as most Asian isolates are either proline-requiring (Pro') or prototrophic. ${ }^{2}$ Serotyping is based on the differential recognition of separate panels of monoclonal antibodies (mAbs) against the outer membrane proteins IA (PIA) or IB (PIB) of $N$ gonorrhoeae strains. Serotyping is occasionally subjective and may be affected by batch-to-batch variation of mAbs. ${ }^{3}$ Moreover, predominant PIB serovars such as IB-3 and IB-7 may not be sufficiently discriminated, while other serovars may be overdiscriminated. ${ }^{4}$ Recently, polymerase chain reaction (PCR) has gained popularity for the characterisation of strains belonging to certain bacterial species. Random amplification of polymorphic DNA (RAPD), also known as arbitrarily-primed PCR (AP-PCR) has been used to differentiate strains of Helicobacter pylori ${ }^{5}$, Listeria monocytogenes $^{6}$ and Clostridium difficile ${ }^{7}$. RAPD is a rapid and simple technique but is often fraught with the generation of artifactual (false positive, false negative, or both) bands which can bias data interpretation. ${ }^{8}$

We describe here a method based on PCR amplification of the gonococcal outer membrane PIB gene combined with restriction fragment length polymorphism (RFLP) analysis that can further differentiate strains belonging to the major PIB serovars of $N$ gonorrhoeae.

\section{Materials and methods}

Gonococcal strains Forty seven random isolates obtained from male and female patients attending a local STD clinic between June and August 1986 were selected for this study. The culture conditions and DNA extraction have been described previously. ${ }^{4}$

Auxotyping and serotyping The strains were auxotyped, and serotyped with a panel of six mAbs specific for PIB ${ }^{1}$ (tables 1 and 2). There were only two auxotypes: 17 strains were prototrophic (S4, S7, S12, S21, S22, S25, S31, S33, S36, S39, S48, S50, S52, S53, S56, S57 and $S 58$ ) and 30 strains were proline-requiring (S1, S2, S3, S5, S8, S10, S11, S16, S17, S18, S19, S20, S24, S26, S27, S28, S30, S32, 
Figure 1 Agarose gel electrophoresis of PIB gene PCR products cleaved with CfoI. Representative CfoI $P C R-R F L P$ profiles I-VI (table 1) are shown in lanes 1-6, respectively. Lanes M: 123 bp DNA ladder marker.
Figure 2 Agarose gel electrophoresis of PIB gene PCR products cleaved with MspA1I. Representative MspAII PCR-RFLP profiles I-V (table 2) are shown in lanes 1-5, respectively. Lanes $M: 123$ bp DNA ladder marker.
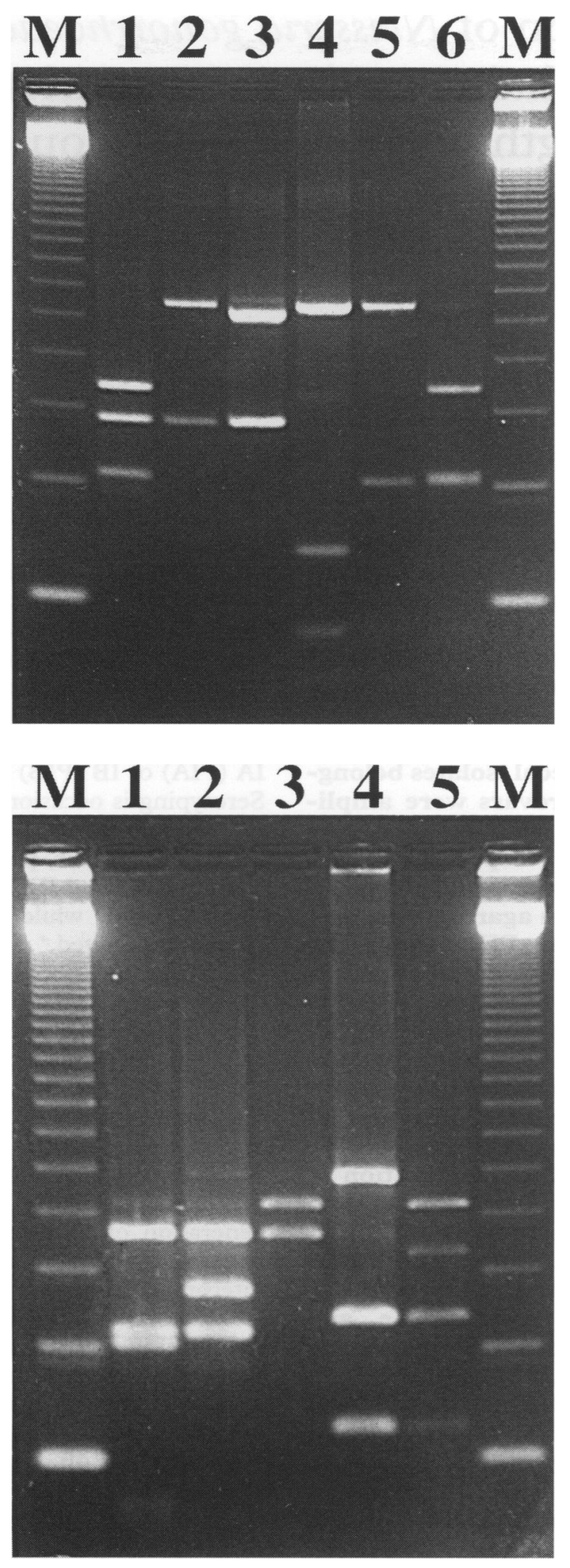

S34, S35, S37, S38, S40, S41, S43, S44, S45, S46, S51 and S55).

Oligonucleotide primers A pair of PCR primers OMG3 (5' TAACCAAAAAAGGAATACAGCA $3^{\prime}$ ) and OMG8 (5' CAGGCTTT TTGTTGATACCA $3^{\prime}$ ), corresponding to nucleotides $49-70$ and $1148-1129^{10}$, respectively was employed to amplify $\sim 1 \mathrm{~kb}$ of the PIB gene of $N$ gonorrhoeae. The primers were chemically synthesised and HPLC-purified (New England Biolabs, Beverly, MA, USA).
PCR amplification PCR was performed in a $50 \mu \mathrm{l}$ reaction mixture containing $1 \times$ SuperTaq buffer, $0 \cdot 25 \mathrm{U}$ of SuperTaq DNA polymerase (HT Biotechnology, Cambridge, UK), $0.2 \mu \mathrm{M}$ of each primer, $0.2 \mathrm{mM}$ each of the four dNTPs and $50 \mathrm{ng}$ of bacterial DNA, subjected to 30 cycles of $95^{\circ} \mathrm{C}$ for $30 \mathrm{~s}, 60^{\circ} \mathrm{C}=$ for $30 \mathrm{~s}$ and $72^{\circ} \mathrm{C}$ for $1 \mathrm{~min}$. Prior to restriction enzyme digestion, $5 \mu \mathrm{l}$ of each amplified product were electrophoresed on $2 \%$ agarose gels stained with ethidium bromide.

Selection of restriction endonucleases Published $\overrightarrow{\vec{m}}$ nucleotide sequences of PIB genes of $10 N$ gonorrhoeae strains S7, S386, S11, S34, S22,흐 S16, S36, MS11, P9 and R10 (belonging to serovars IB-1, IB-2, IB-4, IB-5, IB-7, IB-14, IB-19, IB-9, IB-26 and IB-3, respectively) ${ }^{10-130}$ were analysed using the DNASIS softwareprogramme (Hitachi, Brisbane, CA, USA) tosearch for useful restriction enzyme cleavage $\vec{\omega}$ sites. The enzymes $C f o I$ and $M s p A 1 \mathrm{I}$ (whose recognition sequences are GCG $\downarrow C$ and $\mathrm{C}(\mathrm{A} / \mathrm{C}) \mathrm{G} \downarrow \mathrm{C}(\mathrm{G} / \mathrm{T}) \mathrm{G}$, respectively) were thus.chosen on the basis of their ability to generate suitable restriction profiles of the target frag- $\mathrm{W}$ ments. Other enzymes such as Sau3AI, HpaII윽 and $K p n I$ have been used by Gill et al ${ }^{14}$ to dif-ferentiate between PIA, PIB and PIA/PIB hybrid strains. However, they were unsuitable@ for differentiating PIB strains as Sau3AI does not have cleavage sites in any of the $10 \stackrel{\Phi}{-}$ published strains, while $K p n I$ has only one $\overrightarrow{0}$ site, and HpaII has between 9-11 sites whichor generate too many restriction fragments of similar sizes.

Restriction enzyme digestion To the remaining volume of PCR product, $1 \times$ restriction enzyme buffer and $10 \mathrm{U}$ of the corresponding $\mathbb{D}$ restriction enzyme were added, and incubated $\vec{F}$ at $37^{\circ} \mathrm{C}$ for 5 hours. The digested products 3 were electrophoresed on $2 \%$ agarose gels stained with ethidium bromide and the fragments were sized with 123 bp DNA ladder? markers (Gibco BRL, Gaithersburg, MD, USA).

\section{Results}

Expected products of $\sim 1 \mathrm{~kb}$ were obtained $\stackrel{\circ}{\circ}$ after PCR amplification of the PIB genes of allo the $47 N$ gonorrhoeae strains tested. Six distinct PCR-RFLP profiles with $C f o$ I digestion ${ }^{\circ}$ (fig 1), and five different PCR-RFLP profiles N with $M s p A 1$ I digestion (fig 2) were observed.N All the strains were tested at least three times, and the resultant PCR-RFLP patterns wereo consistent and reproducible.

Tables 1 and 2 diplay the distribution of the 47 serotyped strains according to PCR- $-\frac{7}{0}$ RFLP patterns obtained after digestion with

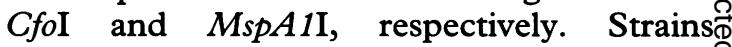
belonging to serovars such as IB-2 and IB- $3 \frac{0}{0}$ could be further differentiated by $C f o I$ PCRRFLP, each into four PCR-RFLP profiles.응 However, eight IB-7 and five IB-19 strainswere clustered into $C f o I$ PCR-RFLP profile IV, while only two other IB-7 and one other IB-19 strains had different $C f o I$ profiles. Similarly, MspA1I PCR-RFLP also differentiated strains of the same serovar (for example IB-1 and IB-2) into distinct PCR-RFLP 
Table 1 Classification of $47 \mathrm{~N}$ gonorrhoeae strains according to their respective CfoI PCR-RFLP profiles

\begin{tabular}{|c|c|c|c|}
\hline $\begin{array}{l}\text { PCR-RFLP } \\
\text { profile }\end{array}$ & $\begin{array}{l}\text { Major fragments } \\
(b p)\end{array}$ & Serovar & Strains \\
\hline I & $\begin{array}{l}420 \\
345 \\
255\end{array}$ & $\begin{array}{l}\text { IB-1 } \\
\text { IB-2 } \\
\text { IB-3 } \\
\text { IB-4 } \\
\text { IB-6 } \\
\text { IB-14 } \\
\text { IB-19 }\end{array}$ & $\begin{array}{l}\text { S7, S20 } \\
\text { S2, S10 } \\
\text { S31, S40, S52 } \\
\text { S4 } \\
\text { S27 } \\
\text { S16 } \\
\text { S3 }\end{array}$ \\
\hline II & $\begin{array}{l}690 \\
345\end{array}$ & $\begin{array}{l}\text { IB-1 } \\
\text { IB-2 } \\
\text { IB-3 } \\
\text { IB-5 } \\
\text { IB-6 }\end{array}$ & $\begin{array}{l}\text { S24, S53, S55 } \\
\text { S44, S58 } \\
\text { S8, S33 } \\
\text { S34 } \\
\text { S18, S38, S51 }\end{array}$ \\
\hline III & $\begin{array}{l}640 \\
345\end{array}$ & IB-3 & $\mathrm{S} 12, \mathrm{~S} 25$ \\
\hline IV & $\begin{array}{l}690 \\
165 \\
105\end{array}$ & $\begin{array}{l}\text { IB-2 } \\
\text { IB-3 } \\
\text { IB-4 } \\
\text { IB-6 } \\
\text { IB-7 } \\
\text { IB-19 }\end{array}$ & $\begin{array}{l}\text { S5 } \\
\text { S21 } \\
\text { S11, S48 } \\
\text { S17 } \\
\text { S22, S26, S28, S30, S41, S43, S50, S57 } \\
\text { S32, S35, S36, S37, S56 }\end{array}$ \\
\hline V & $\begin{array}{l}690 \\
255\end{array}$ & $\begin{array}{l}\text { IB-2 } \\
\text { IB-7 }\end{array}$ & $\begin{array}{l}\text { S46 } \\
\text { S1, S19 }\end{array}$ \\
\hline VI & $\begin{array}{l}430 \\
255\end{array}$ & $\begin{array}{l}\text { IB-6 } \\
\text { IB-9 }\end{array}$ & $\begin{array}{l}\text { S39 } \\
\text { S45 }\end{array}$ \\
\hline
\end{tabular}

profiles. However, clustering of seven IB-3, five IB-6, six IB-7 and five IB-19 strains was observed.

The discriminatory power of auxotyping, serotyping and PCR-RFLP was compared (table 3). PCR-RFLP with both $C f o I$ and $M s p A 11$ could differentiate the $47 N$ gonorrhoeae isolates into 11 subtypes. Combined serovar/PCR-RFLP data were found to be more discriminatory than the auxotype/ serovar typing system alone, yielding 23 and 21 subtypes with $C f o \mathrm{I}$ and $M s p A 1 \mathrm{I}$ digests, respectively; compared with only 17 auxotype/serovar classes among the 47 strains. When auxotyping, serotyping and PCRRFLP analysis were combined, the strains could be further differentiated into 31 sub-

Table 2 Classification of $47 \mathrm{~N}$ gonorrhoeae strains according to their respective MspA1I PCR-RFLP profiles

\begin{tabular}{|c|c|c|c|}
\hline $\begin{array}{l}P C R-R F L P \\
\text { profile }\end{array}$ & $\begin{array}{l}\text { Major fragments } \\
(b p)\end{array}$ & Serovar & Strains \\
\hline I & $\begin{array}{l}430 \\
260 \\
245\end{array}$ & $\begin{array}{l}\text { IB-1 } \\
\text { IB-2 } \\
\text { IB-3 } \\
\text { IB-4 } \\
\text { IB-5 } \\
\text { IB-6 } \\
\text { IB-9 } \\
\text { IB-14 }\end{array}$ & $\begin{array}{l}\text { S7, S20 } \\
\text { S2, S10 } \\
\text { S8, S12, S25, S31, S33, S40, S52 } \\
\text { S4 } \\
\text { S34 } \\
\text { S18, S27, S38, S39, S51 } \\
\text { S45 } \\
\text { S16 }\end{array}$ \\
\hline II & $\begin{array}{l}430 \\
325 \\
260\end{array}$ & $\begin{array}{l}\text { IB-1 } \\
\text { IB-2 }\end{array}$ & $\begin{array}{l}\text { S53, S55 } \\
\text { S58 }\end{array}$ \\
\hline III & $\begin{array}{l}515 \\
430\end{array}$ & $\begin{array}{l}\text { IB-1 } \\
\text { IB-2 } \\
\text { IB-7 } \\
\text { IB-19 }\end{array}$ & $\begin{array}{l}\text { S24 } \\
\text { S44, S46 } \\
\text { S1, S19 } \\
\text { S36 }\end{array}$ \\
\hline IV & $\begin{array}{l}595 \\
280 \\
160\end{array}$ & $\begin{array}{l}\text { IB-2 } \\
\text { IB-3 } \\
\text { IB-4 } \\
\text { IB-6 } \\
\text { IB-7 } \\
\text { IB-19 }\end{array}$ & $\begin{array}{l}\text { S5 } \\
\text { S21 } \\
\text { S11, S48 } \\
\text { S17 } \\
\text { S22, S26, S28, S30, S41, S43 } \\
\text { S3, S32, S35, S37, S56 }\end{array}$ \\
\hline V & $\begin{array}{l}515 \\
280 \\
160\end{array}$ & IB-7 & S50, S57 \\
\hline
\end{tabular}

Table 3 Comparison of auxotype, serovar and PCRRFLP in differentiating $47 \mathrm{~N}$ gonorrhoeae strains

\begin{tabular}{lc}
\hline Classification method & $\begin{array}{c}\text { No of } \\
\text { subtypes }\end{array}$ \\
\hline Auxotyping & 2 \\
Serotyping & 10 \\
PCR-RFLP (CfoI) & 6 \\
PCR-RFLP (MspAII) & 5 \\
PCR-RFLP (CfoI)/PCR-RFLP (MspA1I) & 11 \\
Auxotype/Serovar & 17 \\
Auxotype/PCR-RFLP (CfoI) & 10 \\
Auxotype/PCR-RFLP (MspA1I) & 9 \\
Serovar/PCR-RFLP (CfoI) & 23 \\
Serovar/PCR-RFLP (MspA1I) & 21 \\
Auxotype/Serovar/PCR-RFLP (CfoI) & 31 \\
Auxotype/Serovar/PCR-RFLP (MspA1I) & 28 \\
Auxotype/Serovar/PCR-RFLP (CfoI)/PCR-RFLP & 34 \\
(MspA1I) & 34 \\
\hline
\end{tabular}

types using $C f o I$, or 28 subtypes using MspA1I. A total of 34 gonococcal subtypes could be differentiated when auxotyping and serotyping were combined with PCR-RFLP analyses using $C f o \mathrm{I}$ and $M s p A 1 \mathrm{I}$.

Some strains, for example serovar IB-7 strains S26, S28, S30, S41 and S43 (Pro-), could not be further differentiated by PCRRFLP, analysis serotyping, auxotyping either individually or in combination.

\section{Discussion}

There are a number of limitations of serotyping. For example, some isolates cannot be serotyped by the standard panel of mAbs. ${ }^{15}$ Moreover, serotyping requires specialised reagents, is expensive to maintain and is available only to a few reference centres. In contrast, all the strains in this study could be amplified by PCR as the primers were designed to anneal to the less variable termini of the PIB gene. ${ }^{16}$ The PCR-RFLP method can also be used to study variation in $N$ gonorrhoeae as it is not limited by the availability of existing or new mAbs. ${ }^{14} 15$

In this study, we found that PCR-RFLP can be used to differentiate strains belonging to PIB serovars, demonstrating its usefulness for inter- and intra-serotypic discrimination of $N$ gonorrhoeae strains. With our PCR-RFLP method, strains belonging to a predominant serovar such as IB-3 could be further differentiated. Although IB-3 strains S12, S21, S31 and $\mathrm{S} 33$ could not be differentiated by auxotyping and serotyping, they could be distinguished from one another by PCR-RFLP analysis. PCR-RFLP could thus provide a higher degree of discrimination among gonococcal strains. Interestingly, IB-7 strains S26, S28, S30, S41 and S43 as well as IB-19 strains S32, S35 and S37 could not be further differentiated by PCR-RFLP, serotyping or auxotyping, suggesting that these strains may either be epidemiologically related or were derived from the same clone.

There was no absolute correlation between serotypes and PCR-RFLP profiles. Certain strains belonging to different serovars exhibited identical PCR-RFLP profiles, while some strains of the same serovar displayed different PCR-RFLP profiles. This may be attributed to the occurrence of restriction enzyme sites 
outside of the regions responsible for encoding epitopes recognised by mAbs. Alternatively, silent or conservative nucleotide mutations could modify restriction sites without affecting epitope recognition by the mAbs.

From the published sequence of strain R10 (serovar IB-3) characterised in the USA, ${ }^{13}$ predicted PCR-RFLP profiles with $C f o I$ ( 640 and $345 \mathrm{bp}$ fragments) and MspA1I (430, 260 , and $245 \mathrm{bp}$ fragments) were found to be similar to those of strains S12 and S25 (also belonging to serovar IB-3). The PCR-RFLP profiles predicted from the published PIB sequences of strains S7, S11, S16, S22, S34 and S36 also correlated with the actual profiles on gel electrophoresis, thereby further supporting the reliability of our method. Our present study includes only $47 \mathrm{~N}$ gonorrhoeae strains belonging to 10 serovars. More PCRRFLP profiles may be obtained with a larger number of strains belonging to the same or other serovars. In addition, the discriminatory power of PCR-RFLP analysis may be increased if more than two suitable enzymes were to be employed. It would be interesting to investigate whether this method can discriminate strains isolated from various geographical locations.

We have previously sequenced the hypervariable regions ${ }^{17}$ of the gonococcal PIB genes of serovar IB-3, IB-7, ${ }^{18}$ IB-4 and IB-5 strains. ${ }^{9}$ The PCR-RFLP profiles were identical for serovar IB-3 strains S31, S40 and S52 which also shared identical nucleotide and predicted amino acid sequences of the hypervariable region of the PIB gene. PCR-RFLP analysis can be used as a preliminary screening method to type new gonococcal isolates prior to direct PCR sequencing which is more laborious and time-consuming. PCR-RFLP can be used as an adjunct to auxotyping, particularly due to the restricted number of auxotypes being encountered in a certain geographical area. Moreover, PCR-RFLP is rapid and easy to perform compared with ribotyping ${ }^{19}$ and multilocus enzyme electrophoresis $^{20}$. Thus, the PCR-RFLP method can augment existing typing methods such as auxotype/serovar classification to provide a higher degree of discrimination and for monitoring the spread of $N$ gonorrhoeae in outbreak situations.
This work was supported by NUS research grant RP3920320. $Q$ C Lau is an NUS research scholar. We thank S Sarafian and J Knapp, Centers for Disease Control, Atlanta, GA, USA for the auxotyping and serotyping data.

1 Sarafian SK, Knapp JS. Molecular epidemiology of gonorrhea. Clin Microbiol Rev 1989;2(Suppl.):S49-S55.

2 Poh CL, Ocampo JC, Sng EH, Bygdeman SM. Characterisation of PPNG and non-PPNG Neisseria gonorrhoeae isolates from Singapore. Genitourin Med 1991 67:389-93.

3 Gill MJ. Serotyping Neisseria gonorrhoeae: a report of the Fourth International Workshop. Genitourin Med 1991 67:53-7.

4 Poh CL, Lau QC. Subtyping of Neisseria gonorrhoeae auxotype-serovar groups by pulsed-field gel electrophoresis. f Med Microbiol 1993;38:366-70.

5 Akopyanz N, Bukanov NO, Westblom TU, Kresovich S, Berg DE. DNA diversity among clinical isolates of Helicobacter pylori detected by PCR-based RAPD fingerprinting. Nucleic Acids Res 1992;20:5137-42.

6 Mazurier SI, Wernars K. Typing of Listeria strains by random amplification of polymorphic DNA. Res Microbiol 1992;143:499-505.

7 Barbut F, Mario N, Delmée M, Gozian J, Petit JC. Genomic fingerprinting of Clostridium difficile isolates by Genomic fingerprinting of Clostridium difficile isolates by using a random amplified polymorphic DNA
assay. FEMS Microbiol Lett 1993;114:161-6.

8 Lamboy WF. Computing genetic similarity coefficients from RAPD data: correcting for the effects of PCR artifacts caused by variation in experimental condition PCR Methods Applic 1994;4:38-43.

9 Lau QC, Chow VTK, Poh CL. Polymerase chain reaction and direct sequencing of Neisseria gonorrhoeae protein IB gene: partial nucleotide and amino acid sequence analysis of strains S4, S11, S48 (serovar IB4) and S34 (serova IB5). Med Microbiol Immunol 1993;182:137-45.

10 Butt NJ, Lambden PR, Heckels JE. The nucleotide sequence of the por gene from Neisseria gonorrhoeae strain Res 1990;18:4258.

11 Chow VTK, Lau QC, Poh CL. Mapping of serovar-specific monoclonal antibody epitopes by DNA and amino acid sequence analysis of Neisseria gonorrhoeae outer membrane protein IB strains. Immunol Infect Dis 1994; 4:202-6

12 Carbonetti NH, Simnad VI, Seifert HS, So M, Sparling PF. Genetics of protein I of Neisseria gonorrhoeae: construction of hybrid porins. Proc Natl Acad Sci USA 1988;85:6841-5.

13 Gotschlich EC, Seiff ME, Blake MS, Koomey M. Porin protein of Neisseria gonorrhoeae: cloning and gene structure. Proc Natl Acad Sci USA 1987;84:8135-9.

14 Gill MJ, Jayamohan J, Lessing MPA, Ison CA. Naturally occurring PIA/PIB hybrids of Neisseria gonorrhoeae. occurring PIA/PIB hybrids of Neisse

15 Young H, Moyes A, Tait IB, McCartney AC, Gallacher G. Non-typable quinolone-resistant gonococci. Lancet 1990;335:604.

16 van der Ley $P$, Heckels JE, Virji M, Hoogerhout $P$, Poolman JT. Topology of outer membrane porins in pathogenic Neisseria spp. Infect Immun 1991;59:2963-71.

17 Butt NJ, Virji M, Vayreda F, Lambden PR, Heckels JE. Gonococcal outer-membrane protein PIB: comparative sequence analysis and localization of epitopes which are recognized by type-specific and cross-reacting monoclonal antibodies. $\mathcal{F}$ Gen Microbiol 1990;136:2165-72.

18 Poh CL, Lau QC, Chow VTK. Differentiation of Neisseria gonorrhoeae IB-3 and IB-7 serovars by direct sequencing of protein IB gene and pulsed-field gel electrophoresis. of protein IB gene and pulsed-fiel

19 Poh CL, Khng HP, Lim CK, Loh GK. Molecular typing of Neisseria gonorrhoeae by restriction fragment length of Neisseria gonorrhoeae by restriction fragment
polymorphisms. Genitourin Med 1992;68:106-10.

20 Poh CL, Ocampo JC, Loh GK. Genetic relationships among Neisseria gonorrhoeae serovars analysed by multilocus enzyme electrophoresis. Epidemiol Infect 1992;108 31-38. 